\title{
EFFECT OF POTASSIUM NITRATE POISONING ON SOME BLOOD SERUM BIOCHEMICAL PARAMETERS IN RATS
}

\author{
M.B. MAHMOOD ${ }^{*}$ O.H. AZEEZ ${ }^{* *}$ and J.S. HASSAN ${ }^{* *}$ \\ * Department of Veterinary Internal medicine and surgery, \\ ** Department of Veterinary Public Health, Faculity of Veterinary Medicine, University of Dohuk, Dohuk, Iraq. \\ Email: mahmoodbasher@yahoo.com
}

\section{ABSTRACT}

Received at: $23 / 10 / 2013$

The present study was conducted to investigate the toxicity of potassium nitrate on blood serum glucose, cholesterol levels, alanine aminotransferase (ALT), Aspartate aminotransferase (AST) activity levels, and the possible ameliorative effect of ascorbic acid (Vitamin C). Male Wister rats are used as experimental

Accepted: 15/12/2013 model divided into three groups (each of 6-8 rats) and treated for six weeks as follows: Group 1 : served as control: Group 2 : received $2 \%$ potassium nitrate added to the concentrated forage and Group 3 : received $2 \%$ potassium nitrate together with $1 \%$ ascorbic acid added to rat's concentrat forage. Nitrate treatment in group 2 leads to high significant increase in serum levels of glucose on $3^{\text {rd }}, 4^{\text {th }}$, and $5^{\text {th }}$ weeks, cholesterol level increased significantly on both $4^{\text {th }}$ and $5^{\text {th }}$ weeks, while ALT activity levels increased on the $4^{\text {th }}, 5^{\text {th }}$ and $6^{\text {th }}$ weeks, and AST increased significantly on the $5^{\text {th }}$ and $6^{\text {th }}$ weeks. Addition of ascorbic acid with potassium nitrate, lead to reverse all the parameters nearly to normal. It was concluded that potassium nitrate causes significant toxic effect on some blood serum biochemical parameters which were ameliorated by ascorbic acid.

Key words: Potassium nitrate, blood serum, biochemical parameters, Rats

\section{INTRODUCTION}

Nitrate poisoning has been recorded in several studies (Muslih, 1991) and it can occur in all animals (Jan et al., 2009). Nitrates themselves are not very toxic but nitrite which they converted to be tenfold more toxic than nitrate. In human, nitrate is reduced to nitrite before ingestion in saliva and in the gastrointestinal tract (Kyriakidis et al., 1997 and Jan et al., 2009). In ruminants such as cattle, sheep and goat, the conversion of nitrate to nitrite is carried out by rumen bacteria (Chemlnitskii et al., 1987). Nitrate poisoning affects several biochemical parameters. A previous study indicate that nitrate poisoning cause decrease levels of glucose and alkaline phosphatase in sheep (Majid, 1996), while in study of (Al-kafajii, 1996) in sheep reported an increase in ALT, AST, AP, and glucose. Also (Boukereche, 2007) reported that an increase in levels of glucose, cholesterol, creatinine levels, lactate dehydrogenase, AST, and ALT activity levels in rats.

Vitamin C (Ascorbic Acid) is Known to be potent antioxidant (Ayo et al., 2006 and Suteu et al., 2007), and may augment the function of endogenous free radical scavengers.

The objective of this study was to investigate the nitrate poisoning by potassium nitrate on some blood biochemical parameters in rats as experimental model, and the effect of ascorbic acid when used with nitrate.

\section{MATERIALS and METHODS}

Male Wister rats age 3-4 months and 210-275 gm of body weight were housed in hanging cages and maintained under laboratory controlled of temperature $\left(25 \pm 2^{\circ} \mathrm{C}\right.$ ) and light (14 hour light and 10 hour dark), palliated food concentrated forage and tap water were given.

The animals divided into three groups each of 6-8 rats. Group 1 left as control group; Group 2: potassium nitrate $\left(\mathrm{KNO}_{3}\right)$ (Gerhard Bocham Tuttingreen, Germany) 2\% (Til, 1985) were added to the concentrated forage; Group 3: Coadminstration of potassium nitrate $2 \%$ and ascorbic acid (Vitamin C) 1 $\%$ (Madhuban and Anilava, 2003) were added to the same forage. All treatment were for 6 weeks.

Blood samples were collected every week from the orbital plexus of vein into clear dry centrifuge tubes, allowed to clot; serum was separated after centrifugation at $1500 \mathrm{rpm}$ for 15 minute (Fox et al., 1984). Serum Glucose, cholesterol levels, ALT, and AST activity levels were measured using colorimetric 
assay kits (Bicon Diagnostic GmbH Burbach, Germany).

All data analysed by one way analysis of variance, the specific group differences were determined using Duncan multiple range test; the accepted level of significance was $\mathrm{P}<0.05$ (Bruning and Kintz, 1977).

\section{RESULTS}

After 6 weeks of experiment potassium nitrate $2 \%$ added to rat's forage lead to significantly increased levels of glucose on $3^{\text {rd }}, 4^{\text {th }}, 5^{\text {th }}$ weeks (Table 1) while cholesterol levels was increased on both $4^{\text {th }}$, and $5^{\text {th }}$ weeks (Table 2).

While levels of ALT activity increased in $4^{\text {th }}, 5^{\text {th }}, 6^{\text {th }}$ weeks (Table 3), and AST levels increased significantly on $5^{\text {th }}, 6^{\text {th }}$ weeks (Table 4 ).

When ascorbic acid was added at a dose $1 \%$ to the diet containing nitrate $2 \%$, all parameters reverse nearly to the normal when compared with control, so there are no significant increase on all parameters (Table 1-4).

Table 1: Effect of Potassium Nitrate poisoning alone and with ascorbic acid on blood glucose level (mg/ dl)

\begin{tabular}{|c|c|c|c|c|c|c|c|}
\hline \multirow[t]{2}{*}{ Groups } & \multicolumn{7}{|c|}{ weeks } \\
\hline & 0 & 1 & 2 & 3 & 4 & 5 & 6 \\
\hline \multirow[t]{3}{*}{ Control } & $\mathrm{D}$ & $\mathrm{D}$ & $\mathrm{D}$ & $\mathrm{D}$ & $\mathrm{D}$ & $\mathrm{D}$ & $\mathrm{D}$ \\
\hline & $90.1 \pm 2.7$ & $93.1 \pm 3.1$ & $92.8 \pm 2.0$ & $96.8 \pm 3.7$ & $91.0 \pm 2.1$ & $93.8 \pm 3.5$ & $92.1 \pm 1.8$ \\
\hline & $\mathrm{D}$ & $\mathrm{D}$ & $\mathrm{CD}$ & $\mathrm{AB}$ & A & $\mathrm{ABC}$ & $\mathrm{BCD}$ \\
\hline $\mathrm{KNO}_{3} 2 \%$ & $94.5 \pm 3.7$ & $94.0 \pm 5.0$ & $99.5 \pm 2.4$ & $111.4 \pm 2.0$ & $116.5 \pm 7.5$ & $109.2 \pm 6.0$ & $102.5 \pm 5.1$ \\
\hline KNO3 2\% + & $\mathrm{D}$ & $\mathrm{CD}$ & $\mathrm{D}$ & $\mathrm{CD}$ & $\mathrm{D}$ & $\mathrm{D}$ & $\mathrm{D}$ \\
\hline Vit. C $1 \%$ & $93.8 \pm 5.1$ & $98.2 \pm 2.9$ & $96.2 \pm 2.4$ & $97.8 \pm 2.4$ & $95.4 \pm 3.5$ & $96.6 \pm 4.2$ & $94.5 \pm 4.7$ \\
\hline
\end{tabular}

Value is expressed means $\pm \mathrm{SEM}$ of $6-8$ rats / group.

Different letters indicate significant differences between groups horizontally and vertically at $\mathrm{P}<0.05$.

Table 2: Effect of Potassium Nitrate poisoning alone and with ascorbic acid on blood Cholesterol level (mg/ dl)

\begin{tabular}{|c|c|c|c|c|c|c|c|}
\hline \multirow[t]{2}{*}{ Groups } & \multicolumn{6}{|c|}{ weeks } & \multirow[b]{2}{*}{6} \\
\hline & 0 & 1 & 2 & 3 & 4 & 5 & \\
\hline \multirow{3}{*}{ Control } & D & D & CD & CD & CD & CD & CD \\
\hline & $138.4 \pm 6.3$ & $134.4 \pm 8.1$ & $140.6 \pm 9.2$ & $124.1 \pm 4.3$ & $139.8 \pm 2.9$ & $144.5 \pm 5.2$ & $141.2 \pm 4.7$ \\
\hline & CD & CD & ABCD & $\mathbf{A B C}$ & $\mathbf{A}$ & $\mathbf{A B}$ & BCD \\
\hline $\mathrm{KNO}_{3} 2 \%$ & $141.8 \pm 6.5$ & $145.7 \pm 3.4$ & $153.9 \pm 7.6$ & $158.7 \pm 7.7$ & $170.7 \pm 5.1$ & $168.6 \pm 3.5$ & $151.1 \pm 6.1$ \\
\hline KNO3 2\%+ & D & D & CD & CD & CD & D & D \\
\hline Vit. C $1 \%$ & $136.3 \pm 8.6$ & $134.8 \pm 5.4$ & $141.2 \pm 4.7$ & $143.7 \pm 4.8$ & $139.8 \pm 3.8$ & $137.3 \pm 7.1$ & $134.6 \pm 3.2$ \\
\hline
\end{tabular}

Value is expressed means \pm SEM of 6-8 rats / group.

Different letters indicate significant differences between groups horizontally and vertically at $\mathrm{P}<0.05$. 
Table 3: Effect of Potassium Nitrate poisoning alone and with ascorbic acid on ALT activity level (IU/ L)

\begin{tabular}{|c|c|c|c|c|c|c|c|}
\hline \multirow[t]{2}{*}{ Groups } & \multicolumn{6}{|c|}{ weeks } & \multirow[b]{2}{*}{6} \\
\hline & 0 & 1 & 2 & 3 & 4 & 5 & \\
\hline \multirow[t]{3}{*}{ Control } & D & D & D & D & D & D & D \\
\hline & $19.0 \pm 0.9$ & $19.0 \pm 1.3$ & $19.8 \pm 1.4$ & $20.6 \pm 0.9$ & $20.1 \pm 1.2$ & $20.1 \pm 1.1$ & $19.2 \pm 1.3$ \\
\hline & D & D & D & BC & $\mathbf{A}$ & $\mathbf{A}$ & $\mathbf{A B}$ \\
\hline $\mathrm{KNO}_{3} 2 \%$ & $20.6 \pm 0.8$ & $20.2 \pm 1.2$ & $19.5 \pm 1.3$ & $23.2 \pm 2.4$ & $30.7 \pm 3.1$ & $31.2 \pm 2.4$ & $26.7 \pm 1.9$ \\
\hline KNO3 2\% + & BC & D & BC & BC & BC & BC & BC \\
\hline Vit. C $1 \%$ & $22.1 \pm 4.0$ & $19.4 \pm 3.4$ & $21.9 \pm 3.0$ & $23.5 \pm 2.6$ & $23.9 \pm 5.7$ & $24.3 \pm 2.8$ & $22.8 \pm 2.6$ \\
\hline
\end{tabular}

Value is expressed means \pm SEM of 6-8 rats / group.

Different letters indicate significant differences between groups horizontally and vertically at $\mathrm{P}<0.05$.

Table 4: Effect of Nitrate poisoning alone and with ascorbic acid on AST activity level (IU/ L)

\begin{tabular}{|c|c|c|c|c|c|c|c|}
\hline \multirow[t]{2}{*}{ Groups } & \multicolumn{7}{|c|}{ weeks } \\
\hline & 0 & 1 & 2 & 3 & 4 & 5 & 6 \\
\hline Control & $\begin{array}{c}\text { B } \\
80.7 \pm 2.5\end{array}$ & $\begin{array}{c}\text { B } \\
85.1 \pm 3.2\end{array}$ & $\begin{array}{c}\text { B } \\
82.2 \pm 2.4\end{array}$ & $\begin{array}{c}B \\
82.7 \pm 1.9\end{array}$ & $\begin{array}{c}B \\
84.3 \pm 1.9\end{array}$ & $\begin{array}{c}B \\
83.3 \pm 2.9\end{array}$ & $\begin{array}{c}B \\
82.3 \pm 4.0\end{array}$ \\
\hline $\mathrm{KNO}_{3} 2 \%$ & $\begin{array}{c}\text { B } \\
79.8 \pm 2.7\end{array}$ & $\begin{array}{c}\text { B } \\
78.4 \pm 2.1\end{array}$ & $\begin{array}{c}\text { B } \\
79.5 \pm 2.5\end{array}$ & $\begin{array}{c}\text { B } \\
84.6 \pm 3.8\end{array}$ & $\begin{array}{c}\text { B } \\
89.2 \pm 1.7\end{array}$ & $\begin{array}{c}A \\
99.6 \pm 2.9\end{array}$ & $\underset{101.1 \pm 3.7}{A}$ \\
\hline $\begin{array}{l}\text { KNO3 2\% + } \\
\text { Vit. C } 1 \%\end{array}$ & $\begin{array}{c}\text { B } \\
82.2 \pm 4.1\end{array}$ & $\begin{array}{c}\text { B } \\
85.3 \pm 3.4\end{array}$ & $\begin{array}{c}\text { B } \\
86.4 \pm \mathbf{3 . 6}\end{array}$ & $\begin{array}{c}\text { B } \\
84.3 \pm 2.6\end{array}$ & $\begin{array}{c}\text { B } \\
\mathbf{8 4 . 6} \pm \mathbf{5 . 7}\end{array}$ & $\begin{array}{c}\text { B } \\
87.1 \pm 2.8\end{array}$ & $\begin{array}{c}\text { B } \\
85.1 \pm 2.6\end{array}$ \\
\hline
\end{tabular}

Value is expressed means \pm SEM of 6-8 rats / group. Different letters indicate significant differences between groups horizontally and vertically at $\mathrm{P}<0.05$.

\section{DISCUSSION}

Significant increases in glucose level were observed at $3^{\text {rd }}, 4^{\text {th }}$, and $5^{\text {th }}$ weeks in rats feeding on diet containing $2 \%$ of KNO3. These results are consistent with those of the previous study of Boukerche et al. (2007) in rats and human, and Wiechetek et al. (1993) in rats, but not agree with Majid (1996) in sheep. This may be due to stimulation of the rate of gluconeogenesis (Wiechetek et al., 1993).

Activity of ALT and AST levels increased significantly on $4^{\text {th }}, 5^{\text {th }}, 6^{\text {th }}$ and $5^{\text {th }}, 6^{\text {th }}$, weeks respectively. Similar result reported by Al-kafajii (1996) reported increases in all parameters during $5^{\text {th }}$ week of nitrate treatments.

Table 2 showed that serum cholesterol levels increased significantly on $4^{\text {th }}$, and $5^{\text {th }}$ week of nitrate poisoning. All the changes of glucose, ALT, AST and cholesterol levels can be due to that liver is the major organ that affected directly by nitrate. The pathologic changes and furetimal state of liver play a major role in prognosis of nitrate poisoning in animals (Muslih, 1991 and Hassan, 1991). Also liver plays an active important role in the metabolism of cholesterol, and an increase level of cholesterol and other parameters in the state of poisoning (Chatterjea and Shinde, 2005 and Bishop et al., 2005). Nitrate causes hypoxia (Alkafajii, 1996) lead to increase of activity of ALT, because hypoxia causes hepatocellular injury (Thrall et al., 2004).

In present study Vitamin $\mathrm{C}$ administration to $\mathrm{KNO}_{3}$ treated rats produced no significant changes in all biochemical parameters levels in comparison to control levels and recorded levels return nearly to normal levels. The results of this study agree with those of Saha and Kaviraj (2009) in catfish, and Bassenge et al. (1998) in humans. One of the established mechanisms of toxicity of nitrate is their ability to induce oxidative stress through the generation of free radicals (Singhal et al., 2001 and Manassaram et al., 2006). Vit. C is known to be 
potent antioxidant (Ayo et al., 2006 and Suteu et al., 2007), thus its administration may augment the function of endogenous free radicals scavengers, decrease the deleterious effects of nitrate on body cells (Isyaku, 2009).

In conclusion, the results obtained from present study indicated that toxic effect of potassium nitrate on some biochemical parameters were significant ameliorative effect through Vit. $\mathrm{C}$ by returning this parameters back to nearly to normal.

\section{REFERENCES}

Al-kafajii, N.J. (1996): Nitrate- nitrite intoxication in sheep in Mosul Iraq. Iraqi j Vet Sci. (2): 273-275.

Ayo, J.O.; Minka, N.S. and Mamman, M.M. (2006): Excitability scores of goats administered ascorbic acid and transported during hot- dry conditions. J V Sci. (2): 127-131.

Bassenge, E.; Fink, N.; Skatchkov, M. and Fink, B. (1998): Dietary supplement with vitamin C prevents nitrate tolerance. J. Clin Invest. (1): 67-71.

Bishop, M.L.; Fody, E.P. and Schoeff, L. (2005): Clinical chemistry. $5^{\text {th }}$ ed. Lippincott Williams and Wilkins. USA.

Boukerche, S.; Aouacheri, W. and Saka, S. (2007): Toxicological effects of nitrate: biological study in human and animal. Ann Biol Clion. (7): 385-391.

Bruning, J.L. and Kintz, B.L. (1977): Computational Handbook of Statistics. $2^{\text {nd }}$ ed. Scott Foresman and Co. Glenveiw. Illionois USA. 80-102.

Chatterjea, M.N. and Shinde, R. (2005): Textbook of Medical Biochemistry. $6^{\text {th }}$ ed. Jaypee Brothers. India. 511-513.

Chemlnitskii, G.A.; Loktinov, V.N. and Poloz, D. (1987): Veterinary toxicology. Moscow Agric press. 318.

Fox, J.G.; Cohen, B.J. and Loew, F.M. (1984): Laboratory animal medicine. Academic press Londone UK. 19-20.

Hassan, MG. (1991): Study the hematological, biochemical and histological changes in chronic nitrate poisoning in sheep. (M.Sc. thesis). College of veterinary Medicine. University of Mosul. Iraq.

Isyaku, U.K.; Mohammad Abdel-Halim; Mohammad Eman Okasha; Joseph Olusegun Ayo and Kolawole Victor Olorunshola. (2009): Antioxidant Vitamins $\mathrm{C}$ and $\mathrm{E}$ alleviate the toxicity induced by chronic sodium nitrate administration on sperm count and serum testosterone level in Wister rats. European Journal of Scientific Research. (1): 35-41.
Jan, A.; Diane, B.; Andrew, C.; Jean-Pierre, C.; Eugenia, D.; Alessandro, D.; Maria, L.F.; Peter, F.; Johanna, F.G.; Corrado, L.G.; Philippe, G.; Jadwiga, G.; Gerhard, H.; Niklas, J.; Antonio, M.; Josef, S.; Rolaf, V.L.; Carlos, Van, P. and Philippe, V. (2009): Nitrite as undesirable substance in animal feed. The EFSA Journal. 1017-1047.

Kyriakidis, NB.; Tarantili-Georgiou, K. and TsaniBatzaka, E. (1997): Nitrate and nitrite content of Greek cheese. J Food Comp Analysis. 343-349.

Majid, S.R. (1996): Nitrate- nitrite poisoning in laboratory animals and sheep. (PhD thesis) College of Veterinary Medicine. University of Mosul. Iraq.

Manassaram, D.M.; Bacher, L.C. and Moll, D.M. (2006): A review of nitrate in drinking water: Maternal exposure and adverse reproductive and development outcome. Environmental Health Perspective. (3): 320-327.

Muslih, N.J. (1991): Clinicalelectrophotocardiogeraphical and immunebiological changes in nitrate-nitrite intoxicosis in sheep with and without treatment. (PhD thesis). Stavropol USSR.

Saha, S. and Kaviraj A. (2009): Effects of cypermethrin on some biochemical parameters and its amelioration through dietary supplementation of ascorbic acid in freshwater catfish Heteropneustes fossils. Chemosphere. (9): 1254-1259.

Singhal, S.; Gupta, R. and Gogle, A. (2001): Comparison of antioxidant efficacy of vitamin E,vitamin C, vitamin A and fruit in coronary heart diseases. A controlled trial. Journal of the association of Physician India 327-331.

Suteu, R.; Altuntas, I.; Buyukvanli, B.; Akturk, O.; Koylu, H. and Delibas, N. (2007): The effects of diazinon on lipid peroxidation and antioxidant enzymes in rat's erythrocyte: role of vitamin $\mathrm{E}$ and $\mathrm{C}$. Toxicology and industrial Health. (1): 13-17.

Thrall, M.A.; Baker, D.C.; Campbell, T.W.; Dennis, D.; Fettman, M.J.; Lassen, E.D. and Rebar, D. (2004): Clinical Chemistry. Weiser G. Veterinary Hematology and Clinical chemistry. Lippincott Williams and Wilkins. USA.

Til, H.P. (1985): Short - term (4 weeks) oral toxicity in rats with nitrate added to a cereal basal diet. Interim report. 85-90.

Wiechetek, M.; Garwacki, S.; Karlik, W.; Lewicki, J. and Souffrant, W. (1993): Effect of nitrite on ureagenisis and carbohydrate metabolism in isolated rat hepatocyte. J. Vet. Diagn Invest. (3): 24- 25 . 


$$
\text { تأثير التسمم بنترات البوتاسيوم على بعض القيم الكيموحيوية في مصل دم الجرذان }
$$

\section{محمود بشير محمود ، عمر حسن عزيز ، جيان سلام حسن}

Email: mahmoodbasher@yahoo.com

صمدت تجارب هذه الدر اسة لاختبار التأثير السمي لنترات البوتاسيوم على الكلوكوز ، الكولسترول ، نثاط خميرة ALT، وخميرة

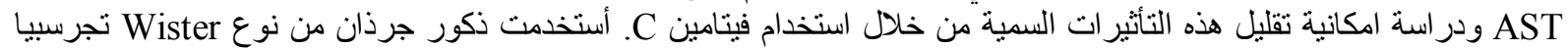

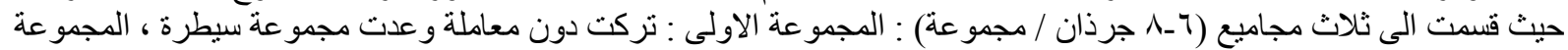

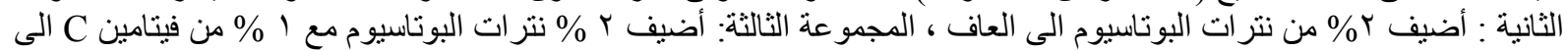

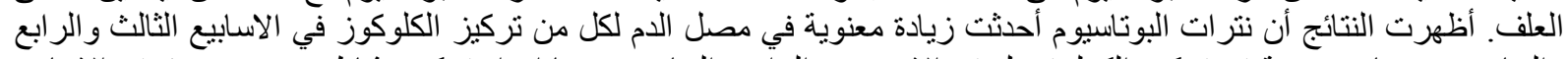

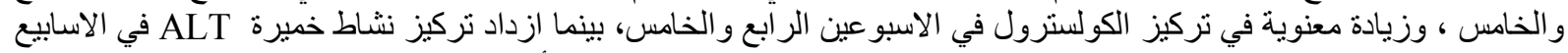

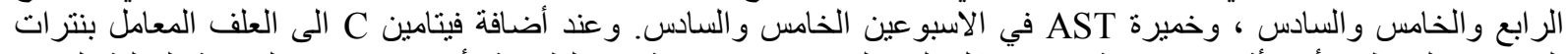

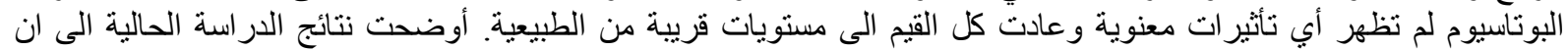

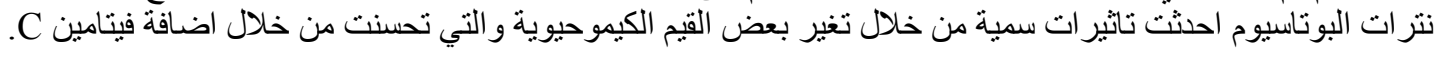

